\title{
Entrepreneurial Behaviour of Pigeon pea Seed Growers: A Study in Raichur District of Karnataka, India
}

\author{
Y. D. Chithra ${ }^{*}$, S. K. Meti $^{2}$, G. N. Maraddi $^{3}$ and B. N. Manjunatha ${ }^{4}$ \\ ${ }^{1}$ Department of Agricultural Extension Bangalore, Ph.D. Scholar, University of Agricultural \\ Sciences, Bangalore-560065, India \\ ${ }^{2}$ Department of Agricultural Extension, Director of extension, University of Agricultural \\ Sciences Raichur-584104, India \\ ${ }^{3}$ Department of Agricultural Extension, Assistant professor, University of Agricultural \\ Sciences Raichur-584104, India \\ ${ }^{4}$ Department of Agricultural Extension Bangalore, Professor and Editor, Communication \\ Centre, University of Agricultural Sciences, Bangalore-560065, India \\ *Corresponding author
}

Keywords

Pigeonpea seed growers, entrepreneurial

behaviour, Zero order correlation, Multiple regression

Article Info

Accepted:

20 May 2018

Available Online:

10 June 2018

\section{A B S T R A C T}

A study was conducted in Raichur district of Karnataka to know the level of entrepreneurial behaviour of pigeon pea seed growers. A sample of 40 respondents was selected for present study by using purposive sampling technique. The five components of entrepreneurial behaviour were undertaken to evaluate the status of entrepreneurial behaviour such as, innovativeness, decision-making ability, achievement motivation, leadership ability and Cosmo politeness. The results revealed that majority $(45.00 \%)$ of the growers belonged to high entrepreneurial behavior category. Whereas, 32.50 and 22.50 per cent of the growers were in medium and low entrepreneurial behaviour category, respectively. The variables like farming experience, annual income, mass media participation and extension participation were showed significant relationship with entrepreneurial behaviour at 5 per cent level of probability. Whereas, risk orientation and management orientation showed significant relationship with entrepreneurial behaviour at 1 per cent level of probability. The $\mathrm{R}^{2}(0.658)$ value indicated that, the twelve independent variables put together, contributed a significant amount of variation $(65.80 \%)$ in the overall entrepreneurial behavior of pigeonpea seed growers.

\section{Introduction}

Nature has endowed our country with vast diversity of land, soil and agro-climatic conditions which enable to produce varied types of crops. The pulses are the major crops of India which are important source of proteins and minerals. India is the largest producer and consumer of pulses in the world accounting for 33 per cent of the world area and 27 per cent of the world production of pulses (Somvanshi et al., 2016). In India, pulses were grown on 23 million hectares area with a production of 15 million tones, with a 
yield of $600 \mathrm{~kg}$ per hectare (Amarender reddy and Devraj mishra, 2010). There is a great need today to enhance the per hectare productivity gradually to boost the pulse production. In this context supply of good quality seeds is an important crucial factor. So, that it becomes imperative to evolve a strategy to produce good seeds and make them available in time at reasonable price to the farming community (Anon., 2004).

Entrepreneurship development in India has enormous potential in terms of diversity of rural occupations. The development of any nation depends primarily on the important role played by entrepreneurs. Hence, the part played by entrepreneurs is of vital importance in a developing country like India. Thus in all economic development activities more attention is being given to entrepreneurship development. Entrepreneurship can also be viewed as a force that mobilizes other resources to meet unmet market demand. The ability to create and build something from practically nothing (Chandramouli et al., 2007), the process of creating value by putting together a unique package of resources to exploit an opportunity (Nagesha, 2005). Dynamic entrepreneurs are considered to be the agent of change in a society (Satish et al., 2017). The studies have not been conducted in a systematic way on the entrepreneurial behavior of seed growers. Even though number of studies have been conducted in India to find out differential characteristics of farmers in adopting farm practices. Most of these studies have tried to find out association between knowledge, adoption, attitude, personal and socio-psychological characteristics. Further, these studies have not been tried to investigate on the role of entrepreneurial behavior. However, only few research studies have been conducted in India on entrepreneurial behavior of farmers.

In a heterogeneous and stratified society like India, it is not adequately realized that, the characteristics which distinguish entrepreneurship may not be because of its different strata. Therefore, the entrepreneurial activity in a particular section of the population has to be considered. Presently, development of seed producing farmers is the primary concern of the country. The role played by entrepreneurs also assumes greater importance. In this context, there is a need for conducting research on the entrepreneurial behavior of seed growers. Hence, an investigation was undertaken to asses the entrepreneurial behavior of pigeon pea seed growers about improved seed production technology and to know the relationship of entrepreneurial behaviour of pigeon pea seed growers with their independent variables.

\section{Materials and Methods}

The present study was conducted in Raichur district of Karnataka because the University of Agricultural Sciences Raichur, (Seed unit) has implemented many seed production programmes in various region of Raichur since 2004. In Raichur district, Raichur taluk had maximum number of seed growers and hence selected purposively as a locale of the study. The villages having maximum number of farmers involved in seed production were listed in descending order in consultation with seed unit UAS Raichur. From the list, three villages namely, Idapnur, Marched, Gunjalli, Huda and gonal having maximum number of seed growers were selected. By using purposive sampling procedure 13 seed growers from Idapnur, 11 seed growers from Marched, 7 seed growers from Gunjalli, 5 seed growers from Huda and 4 seed growers from Gonal were selected thus, the total sample size constituted to 40 respondents. The data were collected with the help of a pre tested interview schedule through personal interview. The entrepreneurial behaviour of pigeon pea seed growers was measured in terms of five dimensions namely, 
innovativeness, decision-making ability, economic motivation, leadership ability and Cosmopoliteness. The scale developed by Chaudhari, et al., (2007) used to measure first four dimensions and Cosmo politeness was measured by using the procedure adopted by Pandeti (2005).

The entrepreneurial behavior categories were formulated as low, medium and high on the basis of mean $\pm \mathrm{SD}$. The correlation analysis was carried out to find out the relationship between personal, socio-economic variables with entrepreneurial behaviour. To explain the contribution of selected factors on entrepreneurial behaviour stepwise multiple regression analysis was carried out.

\section{Results and Discussion}

Overall entrepreneurial behavior of pigeon pea seed growers about seed production practices

It is evident from the Table 1 (Fig. 1) that, the sample as a whole indicated that around 45.00 per cent of the growers belonged to high entrepreneurial behaviour category. Whereas, 32.50 and 22.50 per cent of the growers were in medium and low entrepreneurial behaviour category, respectively. The possible reason for above findings may be due to their high risk orientation, achievement motivation and management orientation.

The other reason might be, their regular contact with agriculture specialists in KVK's and SAU's or might be due to their regular participation in various extension activities like training programmes, krishimelas, agriculture exhibitions, field days and demonstrations. The results are in conformity with the findings of Archana et al., (2014) and Wankhade et al., (2013).

Component wise entrepreneurial behaviour of pigeonpea seed growers

\section{Innovativeness}

The results from Table 2 revealed that majority $(77.50 \%)$ of the growers had high innovativeness, followed by medium $(12.50 \%)$ and low (10.00\%) innovativeness, respectively.

The high innovativeness of growers might be due to their middle age, which have encouraged them to go always for new things and their high risk orientation and achievement motivation. The other reason may be their high annual income and size of land holding. The results are in accordance with the findings of Raghavendra (2010).

\section{Decision making}

It is evident from the Table 2 that, more than half of the growers $(57.50 \%)$ belonged to intermediate decision making ability, and more or less per cent (22.50 and $20.00 \%$ ) of growers were belonged less rational and rational level categories. This might be due to their medium size of land holding. The other possible reason might be that decision making in farming, especially in Indian conditions is very difficult due to ever changing agroclimatic conditions and lack of stabilized price policy. Decision making ability is based on the foresight and confidence of an individual. The results are in confirmity with Suresh (2004) and Satish et al., (2017).

\section{Economic motivation}

The results from the Table 2 showed that, nearly two third $(65.00 \%)$ of the growers had high economic motivation, followed by 20.00 and 15.00 per cent of the growers belonged to medium and low economic motivation categories, respectively.

The probable reason that majority of growers had high economic motivation because they 
have better exposure with various private companies and close interaction with extension personnel. Other reason may be due to surrounding environment like neighbors, relatives, friends were having high standard of living their income responsible for high level of economic motivation. The results are in accordance with the findings of Mehta et al., (2012).

\section{Leadership ability}

It is apparent from Table 2 that, nearly half $(47.50 \%)$ of the growers had medium leadership ability, followed by low (30.00\%) and high (22.50\%) leadership ability, respectively. The pigeonpea seed growers are lack in certain leadership qualities like sufficient knowledge, good supervision etc. The possible reason might be due to their socio-economic status. The other reason being that majority were in middle age group, had only high school education. The results are in conformity with the finding of Suresh (2004) and Nagesha (2005).

\section{Cosmopoliteness}

It is evident from the Table 2 that, over two fifth $(42.50 \%)$ of the growers had high cosmopoliteness, followed by 32.50 and 25.00 per cent of the growers having medium and low level of cosmopoliteness, respectively. Cosmopoliteness is the degree to which a farmer is oriented outside his community to seek information.

Majority fall under medium because, due to their medium economic condition and land holding and due to their outside contact with private companies officials and low may be because of disinterest and illiteracy. The results are in conformity with the findings of Nagesha (2005).

Relationship between socio economic characteristics of seed growers with their entrepreneurial behaviour

Zero order correlation between entrepreneurial behaviour of pigeonpea seed growers with their independent variables

The data in the Table 17 represents the relationship of independent variables of pigeonpea seed growers with their entrepreneurial behaviour. The variables like farming experience, annual income, mass media participation and extension participation were showed significant relationship with entrepreneurial behaviour at 5 per cent level of probability. Whereas, risk orientation and management orientation showed significant relationship with entrepreneurial behaviour at 1 per cent level of probability.

Other variables like age, education, size of land holding, achievement motivation, cropping intensity and information seeking behaviour showed non-significant relationship with entrepreneurial behaviour of pigeonpea seed growers. This inferred that, seed growers with different farming experience, annual income, mass media exposure and extension participation had different entrepreneurial behaviour with regard to new pigeon pea cultivation practices. Annual income of farmers was positively and significantly correlated with their entrepreneurial behaviour. Farmers having higher annual income have higher purchasing power and urge to invest in specialized farm operations.

The higher income itself has motivated the farmers to seek new technologies for improving their standard of living. The farmers with high annual income have good leadership ability and to bear risk and uncertainty in adopting new ideas.

Table.1 Distribution of pigeonpea seed growers according to their overall entrepreneurial 


\begin{tabular}{|c|c|c|c|}
\hline SI. No. & Category & Frequency & Percentage \\
\hline 1 & Low (Mean $-0.425^{*}$ SD) & 9 & 22.50 \\
\hline 2 & Medium $\left(\right.$ Mean $\left.\pm 0.425^{*} \mathrm{SD}\right)$ & 13 & 32.50 \\
\hline 3 & High $($ Mean + 0.425*SD) & 18 & 45.00 \\
\hline & Mean & \multicolumn{2}{|c|}{78.85} \\
\hline & SD & \multicolumn{2}{|c|}{5.43} \\
\hline
\end{tabular}

Table.2 Component wise entrepreneurial behaviour of pigeonpea seed growers

\begin{tabular}{|c|c|c|c|c|c|}
\hline SI. No. & Components & \multicolumn{2}{|c|}{ Category } & $\mathbf{F}$ & $\%$ \\
\hline \multirow[t]{4}{*}{1.} & \multirow[t]{4}{*}{ Innovativeness } & 1. & Low (Mean-0.425*SD) & 4 & 10.00 \\
\hline & & 2. & Medium (Mean $\left.\pm 0.425^{*} \mathrm{SD}\right)$ & 5 & 12.50 \\
\hline & & 3. & High $($ Mean $+0.425 * \mathrm{SD})$ & 31 & 77.50 \\
\hline & & & Mean: 17.10 & & \\
\hline \multirow[t]{4}{*}{2.} & \multirow[t]{4}{*}{ Decision making } & 1. & Less rational (Mean- $0.425 * \mathrm{SD})$ & 9 & 22.50 \\
\hline & & 2. & Intermediate (Mean $\pm 0.425 * \mathrm{SD})$ & 23 & 57.50 \\
\hline & & 3. & Rational (Mean+0.425*SD) & 8 & 20.00 \\
\hline & & & Mean: 18.70 & & \\
\hline \multirow[t]{4}{*}{3.} & \multirow{4}{*}{$\begin{array}{l}\text { Economic } \\
\text { motivation }\end{array}$} & 1. & Low (Mean- $0.425 * \mathrm{SD})$ & 6 & 15.00 \\
\hline & & 2. & Medium (Mean $\pm 0.425^{*} \mathrm{SD}$ ) & 8 & 20.00 \\
\hline & & 3. & High $($ Mean+0.425*SD) & 26 & 65.00 \\
\hline & & & Mean: 36.15 & & \\
\hline \multirow[t]{4}{*}{4.} & \multirow{4}{*}{$\begin{array}{l}\text { Leadership } \\
\text { ability }\end{array}$} & 1. & Low (Mean-0.425*SD) & 12 & 30.00 \\
\hline & & 2. & Medium (Mean $\left.\pm 0.425^{*} \mathrm{SD}\right)$ & 19 & 47.50 \\
\hline & & 3. & High $($ Mean $+0.425 * S D)$ & 9 & 22.50 \\
\hline & & & Mean: 5.65 & & \\
\hline \multirow[t]{4}{*}{5.} & \multirow[t]{4}{*}{ Cosmopoliteness } & 1. & Low (Mean-0.425*SD) & 10 & 25.00 \\
\hline & & 2. & Medium (Mean $\pm 0.425^{*} \mathrm{SD}$ ) & 13 & 32.50 \\
\hline & & 3. & High $($ Mean $+0.425 * S D)$ & 17 & 42.50 \\
\hline & & & Mean: 1.80 & & \\
\hline
\end{tabular}

$* \mathrm{~F}=$ Frequency,$\%=$ Percentage

Table.3 Zero order correlation between entrepreneurial behaviour of pigeonpea seed growers 
with their independent variables

\begin{tabular}{|c|c|c|}
\hline SI. No. & Independent variables & Entrepreneurial behaviour (r value) \\
\hline 1. & Age & $0.260^{\mathrm{NS}}$ \\
\hline 2. & Education & $0.304^{\mathrm{NS}}$ \\
\hline 3. & Size of land holding & $0.312^{\mathrm{NS}}$ \\
\hline 4. & Farming experience & $0.258^{*}$ \\
\hline 5. & Annual income & $0.551 *$ \\
\hline 6. & Risk orientation & $0.301 * *$ \\
\hline 7. & Achievement motivation & $0.084^{\mathrm{NS}}$ \\
\hline 8. & Management orientation & $0.411^{* *}$ \\
\hline 9. & Cropping intensity & $0.149^{\mathrm{NS}}$ \\
\hline 10. & Mass media participation & $0.464 *$ \\
\hline 11. & Extension participation & $0.361^{*}$ \\
\hline 12. & Information seeking behaviour & $0.366^{\mathrm{NS}}$ \\
\hline
\end{tabular}

NS - Non-significant

$\mathrm{r}=$ Correlation co-efficient,

* Significant at 5\%, ** Significant at $1 \%$

Table.4 Step-wise regression analysis of the independent variables of pigeonpea seed growers with entrepreneurial behaviour of pigeonpea growers

$(n=40)$

\begin{tabular}{|l|l|l|l|l|}
\hline $\begin{array}{l}\text { SI. } \\
\text { No. }\end{array}$ & Independent variables & $\begin{array}{l}\text { Regression } \\
\text { coefificient }\end{array}$ & Standard error & t' values \\
\hline 1. & Age & 0.052 & 0.22 & $0.236^{\mathrm{NS}}$ \\
\hline 2. & Education & 0.924 & 0.960 & $0.962^{\mathrm{NS}}$ \\
\hline 3. & Size of land holding & 1.133 & 0.121 & $1.103^{\mathrm{NS}}$ \\
\hline 4. & Farming experience & 1.081 & 0.379 & $1.212^{*}$ \\
\hline 5. & Annual income & 1.051 & 0.3615 & $1.311^{*}$ \\
\hline 6. & Risk orientation & 2.139 & 1.336 & $1.600^{* *}$ \\
\hline 7. & Achievement orientation & 0.353 & 0.831 & $0.425^{\mathrm{NS}}$ \\
\hline 8. & Management orientation & 1.358 & 0.902 & $1.396^{* *}$ \\
\hline 9. & Cropping intensity & 0.011 & 0.054 & $0.120^{\mathrm{NS}}$ \\
\hline 10. & Mass media participation & 1.430 & 0.265 & $1.624^{*}$ \\
\hline 11. & Extension participation & 1.110 & 0.182 & $1.606^{*}$ \\
\hline 12. & Information seeking behaviour & 1.015 & 0.220 & $1.569^{\mathrm{NS}}$ \\
\hline R2: & G5 & & &
\end{tabular}

$\mathrm{R}^{2}: 0.658$

**: Significant at 0.01 probability level, $*$ Significant at 0.05 probability level

Fig.1 Distribution of pigeonpea seed growers according to their overall entrepreneurial 


\section{behaviour}

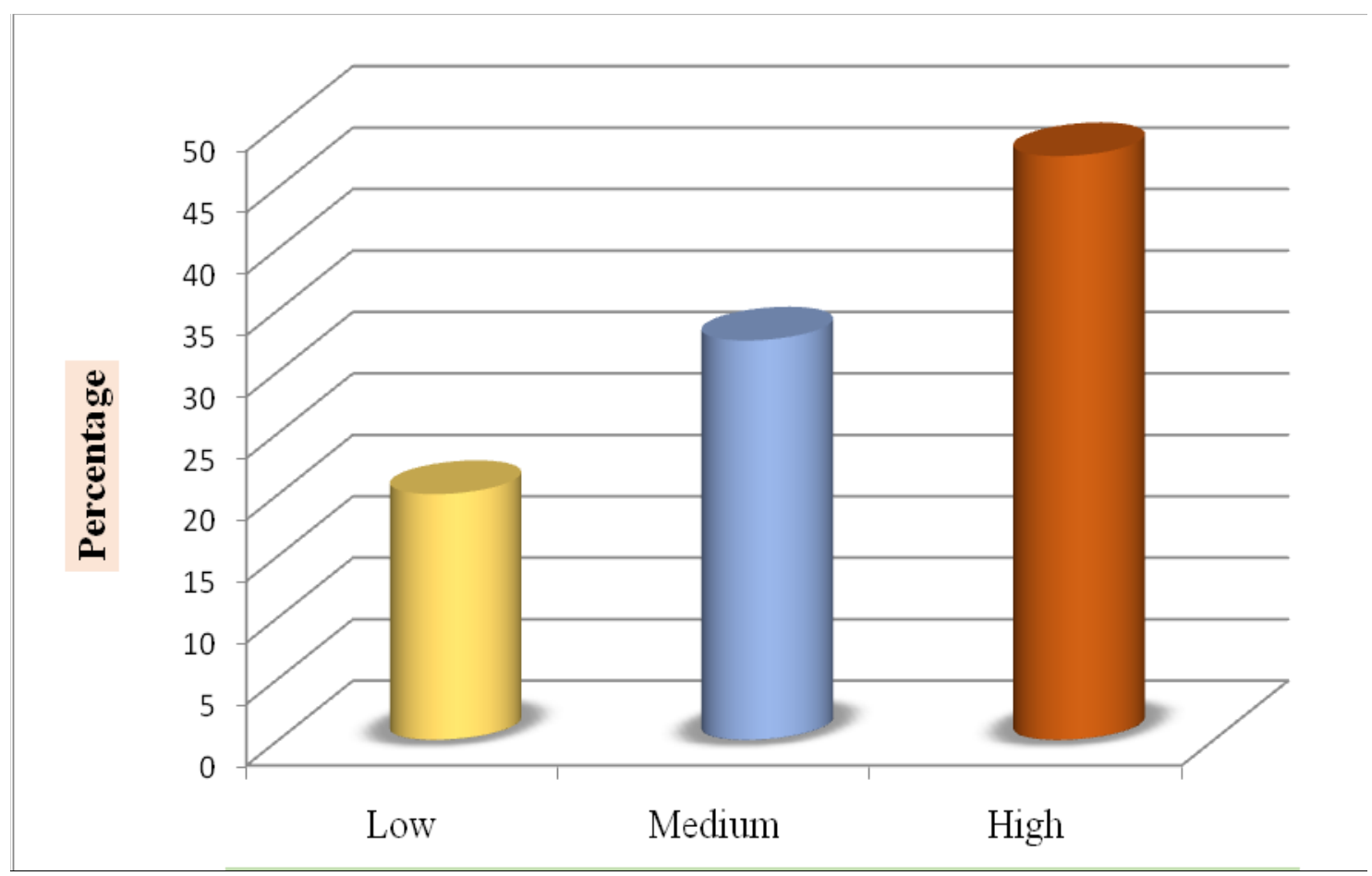

Annual income provides the economic base for the farmer, this was due to positive and significant relationship of risk taking ability, leadership ability, achievement motivation. The results are in confirmity with the reports of Subramanyeshwari and Reddy (2003), Subramanyeshwari et al., (2007), Nagesha (2005), Ravi (2007) and Mehta et al., (2012).

Step wise regression analysis of the different independent variables with entrepreneurial behaviour of pigeonpea seed growers

It is apparent from value coefficient of multiple regression $R^{2}(0.658)$ given in Table 18 that the twelve independent variables put together, contributed a significant amount of variation $(65.80 \%)$ in the overall entrepreneurial behaviour of pigeonpea growers. Further it is also indicated by the table that the independent variables like, farming experience, annual income, mass media participation and extension participation were significant at 5 per cent level of probability. Whereas, risk orientation and management orientation were significant at 1 per cent probability level. It signifies that these independent variables are important predictors of entrepreneurial behaviour of pigeonpea seed growers. The five components viz., farming experience, annual income, risk orientation, management orientation, mass media participation and extension participation were found to be the important contributing factors for entrepreneurial behaviour, which contributes 65.80 per cent to the entrepreneurial behavior.

To raise one unit of entrepreneurial behaviour contribution from management orientation is 1.396 along with other components (Table 4). Management orientation is an important factor which contributes to the overall entrepreneurial behaviour. Orientation of farmers to the management practices in farming and marketing of seeds attributes very much significance to the knowledge, 
skills and abilities of the farmers. The contribution from farming experience is 1.212 along with other components. Likewise, contribution from annual income is 1.311, from risk orientation is 1.600 , from mass media participation is 1.624 and from extension participation is 1.606 with other components, respectively.

Thus all these six components viz., management orientation, farming experience, annual income, risk orientation, mass media participation and extension participation individually and in combination greatly contribute for the entrepreneurial behaviour of farmers. The results are in confirmity with the findings of Aregawi (2014) and Nagesh (2006).

This paper examined the underlying construct "entrepreneurial behaviour" of pigeon pea seed growers in Raichur district of Karnataka state. The study has clearly shown that majority of the farmers had a high level of entrepreneurial behaviour. More than half of the respondents had high level of innovativeness, economic motivation and cosmopoliteness and more than half of the respondents had medium level of decision making ability, and leadership ability. Correlation analysis indicated that the variables like farming experience, annual income, mass media participation and extension participation were showed significant relationship with entrepreneurial behaviour at 5 per cent level of probability. Whereas, risk orientation and management orientation showed significant relationship with entrepreneurial behaviour at 1 per cent level of probability. Therefore, efforts should be made to increase the level of entrepreneurial behaviour through entrepreneurship awareness, intensive training programmes, group discussions, demonstrations, tours, field visits etc., for socio economic upliftment of the pigeon pea seed growers.

\section{Acknowledgement}

I am thankful to pigeon seed growers, UAS Raichur seed unit and National seed corporation Raichur officials who co-operate very kindly and affectionately during collection of data. I also like to acknowledge journal editor and reviewers who helped me in research paper. I am overwhelmed with heartfelt feelings of gratitude and profound indebtedness to my beloved teacher Dr. S. K. METI, Dean (Agri), AC, Raichur and Director of Extension, Department of Agricultural Extension Education, University of Agricultural Sciences, Raichur and Chairman of my Advisory Committee, for his inspiring guidance, subtle and expert help, sustained interest in planning and execution during my research period and all my advisory committee members.

\section{Authors Contribution}

Y. D. Chithra designed the study, performed the statistical analysis, wrote the protocol, and wrote the first draft of the manuscript.

S. K. Meti guided and approved the manuscript

G. N. Maraddi and B. N. Manjunatha, guided and managed the analyses of the study and helped in the literature searches, all authors read and approved the final manuscript."

\section{References}

Amarender Reddy and Devraj Mishra, 2010. Growth and Instability in pulse production in India.

Anonymous, 2004, Hand book of agriculture, Indian Council of Agricultural Research, New Delhi, pp. 1088-1090.

Archana, K. N., Natikar, K. V. and Joshi, S. S., 2014, Entrepreneurial behaviour of commercial seed growers and other 
farmers. Karnataka. J. Agric. Sci., 27(4): (548-550).

Aregawi, L.M., 2014 Entrepreneurial behaviour of seed growers in Ethiopia. J. Development and Agric. Econ., 3(6), pp, 436-412.

Chandramouli, P., Meti, S. K., Hirevenkanagoudar, L. V. and Hanchinal, S. N. 2007. Comparative analysis of entrepreneurial behavior of farmers in irrigated and dry land areas of Raichur district of Karnataka. Karnataka J. Agril. Sc., 20 (2): 320-321.

Chaudhari, R. R., Hirevenkanagoudar, L. V., Hanchinal, S. N. and Mokashi, A.N. 2007. A scale for measurement of entrepreneurial behavior of dairy farmers. Karnataka $J$. Agril. Sc, 20 (4): 792-796.

Mehta, B. M., Shankar, N. M. and Sonawane, M., 2012, Entrepreneurial behaviour of Mango growers of Valsad district of Gujarath state. Indian Res. J. Extn. Edu., 12(1).

Moulik, T. K., 1965, A study on predictive values of some factors of adoption of nitrogen fertilizers and the influence of sources of information on adoption behaviour. Ph. D. Thesis, Indian Agric. Res. Inst., New Delhi.

Nagesh, 2006, Study on entrepreneurial behaviour of pomegranate growers in Bagalkot district of Karnataka. M. Sc. (Agri.) Thesis, Univ. Agric. Sci., Dharwad (India).

Nagesha, P. N., 2005, A study on entrepreneurial behaviour of vegetable seed production farmers of Haveri district. M. Sc. (Agri.) Thesis, Univ. Agric. Sci., Dharwad (India).

Pandeti, C. M., 2005, A study on entrepreneurial behaviour of farmers in Raichur district of Karnataka. M. Sc. (Agri.) Thesis, Univ. Agric. Sci., Dharwad (India).
Raghavendra, K. M., 2010, An impact study on farmers knowledge and adoption level of sunflower demonstration farmers in Bijapur district of Karnataka. M. Sc. (Agri.) Thesis, Univ. Agric. Sci., Dharwad (India).

Ravi, G. K., 2007, A study on entrepreneurial characteristics of SC and ST farmers of Gulbarga district. M. Sc. (Agri.) Thesis, Univ. Agric. Sci., Dharwad (India).

Satish M. S, Santosh, S., Pathade, Manish N. M., Ramesh and K. I. Pordhiya, 2017, Entrepreneurial Behaviour of Dairy Farmers: A Study in Marathwada Region of Maharashtra, India. Int.J.Curr.Microbiol.App.Sci., 6(7): 97-101.

Somvanshi, R. M., Deshmukh, A. N., Mokhale, S.U. and Modase, S. K. 2016, Entrepreneurial behaviour of vegetable growers. Agri Update, 11(3): 239-241.

Subrahmanyeswari, B., Veeraraghava, R. K. and Sudhakar, R. B. 2007. Entrepreneurial behaviour of rural women farmers in dairying: A multidimensional analysis. Livestock research for rural development, 19(15).

Subramanyeswari, B. and Reddy, V. K., 2003, Entrepreneurial behavior of rural dairy women. Madras. Agric. J., 30(1-3): 173175.

Suresh, 2004, Entrepreneurial behaviour of milk producers in Chittoor district of Andhra Pradesh - A critical study. M. V. Sc. Thesis, Acharya N. G. Ranga Agric. Univ., Hyderabad.

Wankhade, R. P., Sagane M. A. and Mankar, D.M., 2013, Entrepreneurial behaviour of vegetable growers. J. Agic. Sci. Digest, 33(2), ISSN: 0253-1500.

\section{How to cite this article:}

Chithra Y. D., S. K. Meti, G. N. Maraddi and Manjunatha B. N. 2018. Entrepreneurial Behaviour of Pigeon pea Seed Growers: A Study in Raichur District of Karnataka, India. Int.J.Curr.Microbiol.App.Sci. 7(06): 1754-1762. doi: https://doi.org/10.20546/ijcmas.2018.706.208 